\title{
Gabon's green gold: a bibliographical review of thirty years of research on okoumé (Aucoumea klaineana Pierre)
}

\author{
Quentin Guidosse ${ }^{(1,2)}$, Patrick du Jardin ${ }^{(1)}$, Lee J.T. White ${ }^{(3,4,5)}$, Ludivine Lassois ${ }^{(1)}$, \\ Jean-Louis Doucet ${ }^{(2)}$
}

\author{
(1) Univ. of Liège - Gembloux Agro-Bio Tech. TERRA. Plant Sciences. Passage des Déportés, 2. BE-5030 Gembloux \\ (Belgium).E-mail: qguidosse@uliege.be \\ (2) Univ. of Liège - Gembloux Agro-Bio Tech. TERRA. Management of Forest Ressources. Passage des Déportés, 2. \\ BE-5030 Gembloux (Belgium). \\ (3) Univ. of Stirling. Faculty of Natural Sciences. Biological and Environmental Sciences. FK9 4LA, Stirling (United \\ Kingdom). \\ (4) Institut de Recherche en Écologie Tropicale. CENAREST. BP843. Libreville (Gabon). \\ ${ }^{(5)}$ Ministère des Eaux, de la Forêt, de la Mer et de l’Environnement, République Gabonaise. BP199. Libreville (Gabon).
}

Received 9 March 2021, accepted 24 January 2022, available online 8 February 2022.

This article is distributed under the terms and conditions of the CC-BY License (http://creativecommons.org/licenses/by/4.0)

Introduction. Aucoumea klaineana Pierre is the most harvested timber species in Central Africa and plays a key role in the economy of Gabon. This tree is considered "Vulnerable" for more than three decades by the IUCN because its population is assumed to have been reduced by at least $50 \%$ as a result of logging. The objective of this review is to synthesize recent and relevant knowledge in order to update this status. It focuses more specifically on ecology, population dynamics, silviculture and impacts of logging.

Literature. Its natural range mainly covers Gabon. It is a light-demanding and gregarious species that forms root anastomoses. It principally establishes itself in abandoned fields and savannahs. In mature forest its regeneration is rare and limited to large gaps. Selective logging only allows significant regeneration along roads. However, at the scale of Gabon, the species is abundant and its renewal is ensured. Legal logging does not threaten the species. However, after decades of logging focusing on best shaped trees, a production of lower quality is feared. The implementation of a thoughtful silviculture could be a solution.

Conclusions. Aucoumea klaineana is not vulnerable under IUCN A1 criterion. However, the maintenance of a high-quality production over the long term calls for the implementation of silviculture based on a thorough knowledge of the factors affecting stand dynamics, especially the role of the rhizosphere. Although long described, the functioning of root anastomoses has never been studied in depth.

Keywords. IUCN, vulnerable species, silviculture, forest ecology, anastomoses, rhizosphere, sustainable management.

L'or vert du Gabon : une synthèse bibliographique de trente années de recherche sur l'okoumé (Aucoumea klaineana Pierre)

Introduction. Aucoumea klaineana Pierre est l'essence de production la plus exploitée d'Afrique centrale et elle joue un rôle fondamental dans l'économie du Gabon. Elle est considérée comme «Vulnérable » depuis plus de trois décennies par l'UICN car sa population est supposée avoir été réduite d'au moins $50 \%$ à cause de l'exploitation forestière. L'objectif de cette revue est de synthétiser les connaissances récentes et pertinentes afin d'actualiser ce statut. Elle se concentre plus particulièrement sur l'écologie, la dynamique des populations, la sylviculture et les impacts de l'exploitation forestière.

Littérature. Il s' agit d'une espèce quasi endémique au Gabon. Elle est héliophile, grégaire et forme des anastomoses racinaires. Elle se régénère principalement dans les champs abandonnés et les savanes. Sa régénération en forêt mature est rare et limitée aux trouées de grande dimension. L'exploitation forestière sélective ne permet une régénération significative que le long des routes. Toutefois, à l'échelle du Gabon, l'espèce est abondante et sa régénération assurée. L'exploitation forestière, si elle respecte les normes légales, ne menace pas l'espèce. Cependant, s'étant focalisée pendant des décennies sur les plus beaux pieds, une production de moindre qualité est redoutée. La mise en œuvre de plantations et d'autres méthodes de régénération pourraient y remédier. 
Conclusions. Aucoumea klaineana n'est pas une espèce vulnérable selon le critère A1 de l'UICN. Néanmoins, le maintien d'une production de qualité sur le long terme nécessite la mise en place d'une sylviculture basée sur une connaissance approfondie des facteurs affectant la dynamique des peuplements, notamment le rôle de la rhizosphère. Bien que des anastomoses racinaires aient été décrites depuis longtemps, leur fonctionnement n'a jamais été étudié.

Mots-clés. UICN, espèce vulnérable, sylviculture, écologie forestière, anastomoses, rhizosphère, gestion durable.

\section{INTRODUCTION}

Aucoumea klaineana Pierre is the most harvested tree in Central Africa (FRMi, 2018) and it plays a key role in the economy of Gabon for more than a century (Meunier et al., 2015). Its commercial name is "okoumé" in French and "gaboon" in English (ATIBT, 2016). Its wood is mainly used for peeling, plywood manufacture and interior joinery. It has several qualities that favour its use, including its straight grain, large log size, low and uniform density (Peguy et al., 2019).

This tree is present at the top of the coat of arms of the Gabonese republic and contributes to the daily life of rural populations. They use it to build their houses, make their dug-out canoes, torches and treat various illnesses. It produces an aromatic, inflammable oleoresin with antioxidant and antiseptic properties (Obame et al., 2014; Aboughe Angone et al., 2015; DeCarlo et al., 2019; Peguy et al., 2020).

Aucoumea klaineana is considered "Vulnerable" since 1998 by the IUCN (https://www.iucnredlist. org/species/33213/9766796) because its population is assumed to have been reduced by at least $50 \%$ as a result of logging (criterion A1). However, this statement is only based on five broad-based references while detailed monographs (Leroy Deval, 1974, 1976a, 1976b; Brunck et al., 1990) and more recent publications have been omitted.

Given the economic importance of A. klaineana, it is essential to reassess its conservation status based on the most recent work. Consequently, the objective of this review is to synthesize the knowledge that can influence the population dynamics of the species. It focuses more specifically on its ecology, silviculture and exploitation. It also highlights issues that need to be better studied in order to ensure sustainable management of A. klaineana populations. It was conducted using the keywords "okoumé" and "aucoumea" in the following search engines: Orbi (ULiège), Libnet (ULiège), Scopus, Google Scholar, the archives of the FORAFRI project (CIRAD) and the archives of the Gembloux Agro-Bio Tech tropical forestry laboratory.

\section{TAXONOMY AND BOTANICAL DESCRIPTION}

Aucoumea is a monotypic genus belonging to the pantropical Burseraceae family. Aucoumea klaineana can reach 50-60 $\mathrm{m}$ in height, $2 \mathrm{~m}$ in diameter and live up to 300 years. The bole is cylindrical with a base either widened or with buttresses which can reach up to $3 \mathrm{~m}$ height (Figure 1a) (Meunier et al., 2015). The slice is pink and exudes a characteristic oleoresin (Figure 1b). Its foliage is diffuse. The leaves are hairless, compound and imparipinnate (Figure 1c). The rachis is up to $40 \mathrm{~cm}$ long, inserted on a hollow grooved petiole. The veins are joined in an arch near the margin of the leaf. The petiole is 3 to $4 \mathrm{~cm}$ long, swollen at the end. Leaflets, 7 to 13 in number, are ovate to oblong, opposite and rounded at the base. The young leaves are red and turn grey-green after a week. The tree is dioecious. Inflorescences can carry a few hundred female flowers or more than a thousand male flowers (Figure 1d). From the outside, flowers are composed by a calyx with five sepals which are tomentose and brownish, triangular in shape and about $5 \mathrm{~mm}$ long. The five petals of about $7 \mathrm{~mm}$ are also tomentose and brownish. Inside, five orange bilobed nectaries form a crown in the center. In male flowers, the ten stamen filaments are thicker and the gynoecium is attenuated. In the female flowers, the anthers are empty and the pistil is more voluminous. A detailed description of flowers of both types can be found in Aubréville (1962) and Grison (1978). The fruit is a dehiscent capsule with five valves (Figure 1e). On opening, it releases spoon-shaped tough parts containing five seeds of 3 to $4 \mathrm{~cm}$ each, enclosed in the winged endocarp (Figure 1f) (Aubréville, 1962). The germination is phanerocotyl and epigea. Cotyledons are foliaceous, rapidly turning green (Figure 1g). The cotyledons persist up to 4 months after sowing (Mapaga et al., 2002).

The development of A. klaineana roots is complex (Leroy Deval, 1974). Lateral roots appear from 10 to 12 weeks. After 10 years and when the typical litter of A. klaineana stands has developed, the taproot atrophies and secondary roots move up towards the shallow soil horizons, between 0 to $25 \mathrm{~cm}$ and spread up to $20 \mathrm{~m}$ around the trees. In mature stands, the secondary roots thicken to form buttresses. Fine roots build up a dense network in the litter. Tertiary roots can form directly at the base of the buttresses, where litter accumulates heavily. Roots of A. klaineana are coarse and shallow, with few branches, but with fine, long and short pear-shaped elements (Figure 6). The root systems form mechanical and functional root fusions called root anastomoses (See 4.5.). 


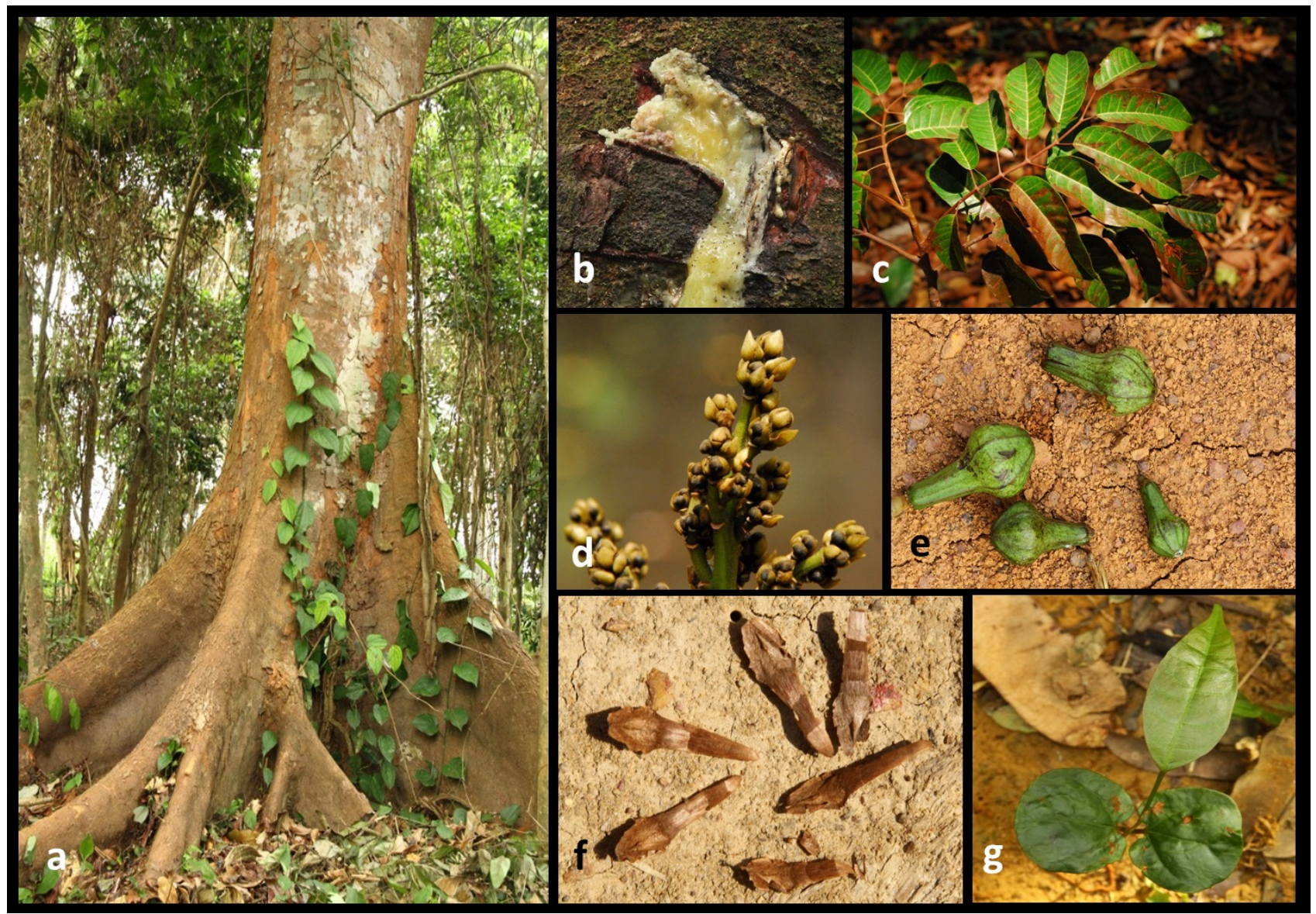

Figure 1. Aucoumea klaineana Pierre (C) J.L. Doucet (a, b, e, f, g) ; Q. Meunier (c, d).

a: cylindrical bole and base with buttresses - fût cylindrique et base contreforts; b: oleoresin - oléorésine; c: compound leaf - feuille composée; $\mathbf{d}$ : inflorescence and flowers - inflorescence et fleurs; $\mathbf{e}$ : fruits - fruits; f: seeds — graines; $\mathbf{g}$ : young seedling with both cotyledons and the first true leaf — jeune plantule présentant les deux cotylédons et la première vraie feuille.

\section{BIOGEOGRAPHY OF POPULATIONS}

\subsection{Distribution}

Aucoumea klaineana is found everywhere in Gabon except in the northeastern third, limited from a line passing through Okondja in the east and between Mitzic and Oyem in the north (Brunck et al., 1990), at all altitudes from sea level to near the summit of Mount Iboundji, one of the highest point in the country (980 m). It is also found in Equatorial Guinea (Río Muni), in south-western Congo and in the extreme south-west of Cameroon (Figure 2).

This current distribution of natural populations of A. klaineana (Figure 2) corresponds remarkably with the so-called "Gabonese" region (Philippon et al., 2018). This is characterised by (i) on average, only $109 \mathrm{~W} \cdot \mathrm{m}^{-2}$ of incident solar irradiation, a large quantity of dark mornings and dark days with a minimum from June to September $\left(80 \mathrm{~W} \cdot \mathrm{m}^{-2}\right)$, i.e. the great dry season; (ii) rainfall of less than $1 \mathrm{~mm} \cdot$ day $^{-1}$ in July and August; (iii) generally colder temperatures and (iv) higher relative humidity in the dry seasons than the rest of Central Africa.

Artificially planted, A. klaineana is found in its native range but also in other regions of Cameroon, Côte d'Ivoire, DRC, Ghana, Madagascar, Indonesia, Malaysia, Suriname and French Guiana. However, the poor performance of A. klaineana plantations outside its natural range seems to confirm that climate is a determining factor for the health of its populations (Brunck et al., 1990).

\subsection{Genetic distribution of populations}

A study of the chloroplast DNA of A. klaineana revealed a geographical structuring which suggested a historic separation into two populations: one in the north, confined to the Cristal Mountains, and the other in the south, on the Chaillu massif. This structuring is thought to be linked to the presence of forest refuges in these areas during glacial periods (Muloko-Ntoutoume 


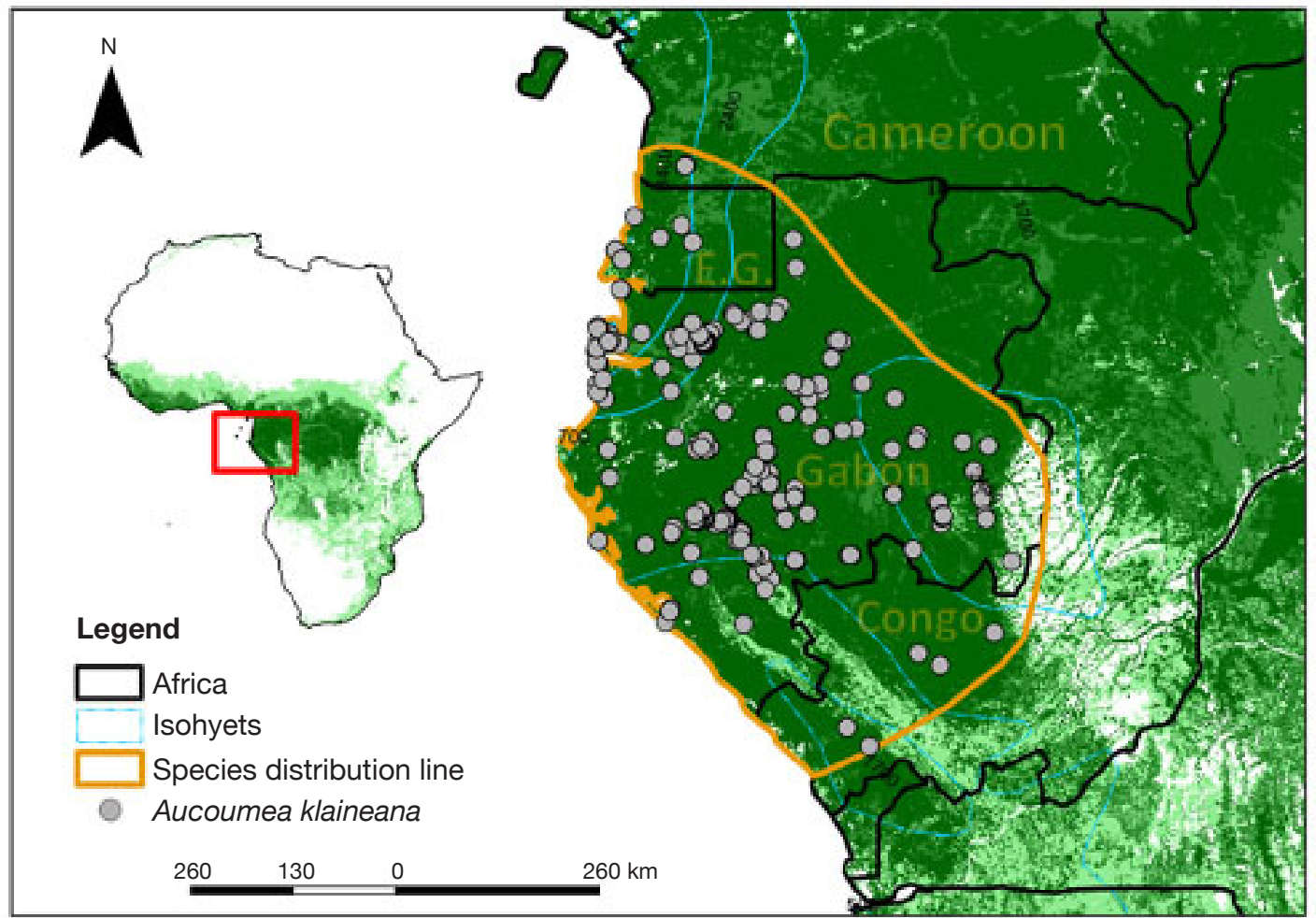

Figure 2. Map of geographical distribution of Aucoumea klaineana - Carte de répartition géographique d'Aucoumea klaineana.

The points of occurrence in grey are taken from the databases of the Global Biodiversity Information Facility (GBIF, 2020) and the RAINBIO database (Dauby et al., 2016). The yellow line depicts the current range of the species - Les points d'occurrence en gris proviennent des bases de données du Global Biodiversity Information Facility (GBIF, 2020) et de la base de données RAINBIO (Dauby et al., 2016). La ligne jaune délimite l'aire de répartition actuelle de l'espèce.

et al., 1999) and is also shown by some mammals such as Mandrillus sphinx L. (Telfer et al., 2003) and Gorilla gorilla gorilla Savage (Anthony et al., 2007).

Born et al. (2011) isolated and used ten polymorphic microsatellites from the nuclear DNA of A. klaineana to undertake a finer analysis, revealing two other distinct genetic units that appear to correspond to two additional refuge areas: the "Doudou" and "Mayombe" massifs (Born et al., 2011) (Figure 3).

\section{ECOLOGY}

\subsection{Temperament}

Aucoumea klaineana has a pioneering and strictly light-demanding temperament. It colonises open environments of natural (e.g. savanna or forest openings) or anthropic origin (e.g. fallow lands), often in dense patches. As such, A. klaineana is generally considered to be a gregarious species.

Leroy Deval (1973) demonstrated that individuals in a population are not simply in close proximity to each other but also establish root fusions (See 4.5.).
In an even-aged stand, stratification takes place from an early age and it appears that the dominant tree in the population retains higher radial growth than the other trees. Thanks to root anastomoses, it benefits from an extension of its rhizosphere and in exchange, it provides water, nutrients and minerals to suppressed trees and stumps which are still alive.

\subsection{Population dynamics and structure}

Aucoumea klaineana can form almost monospecific stands. Its populations are said to follow man, because they regenerate in the post-cultivation fallow (Hymas, 2015). It was nicknamed "the son of cassava" by Aubréville (1948). It is also a coloniser of savannas, with wind dispersed seeds that will carry over $100 \mathrm{~m}$. Delègue et al. (2001) recorded an annual rate of encroachment into savanna of $1 \mathrm{~m} \cdot \mathrm{yr}^{-1}$ by analysing carbon 13 and 14 isotopes in soils. Favier et al. (2004) proposed an empirical model to study the A. klaineana rate of progression at the edge of savannas by linking the age and diameter of the individuals.

Aucoumea klaineana also colonises roadsides, and is sometimes found in large light gaps, but does 


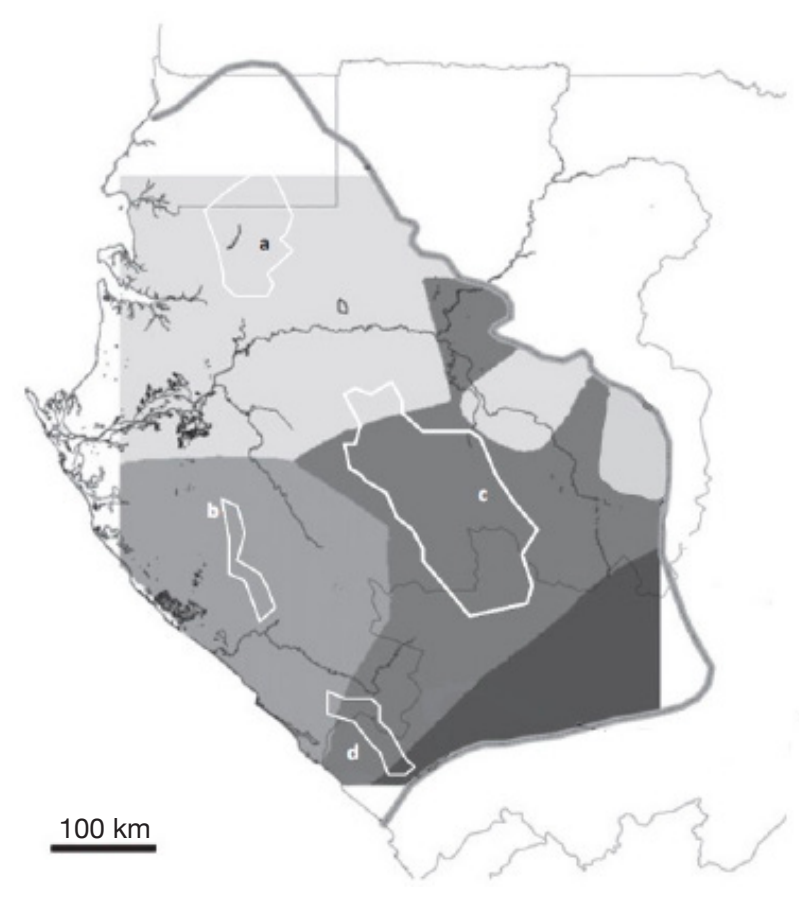

Figure 3. Distribution model of four genetically distinct populations of Aucoumea klaineana described by MulokoNtoutoume et al. (1999) and Born et al. (2011) - Modèle de répartition de quatre populations génétiquement distinctes d'Aucoumea klaineana décrites par Muloko-Ntoutoume et al. (1999) et Born et al. (2011).

The grey line shows the current distribution range of the species. White polygons represent elevated areas : (a) Cristal Mountains, (b) Doudou Mountains, (c) Chaillu Massif and (d) Mayombe massif. They could correspond to refuge areas during the Last Glacial Maximum and they would have led to these four genetically distinct populations depicted by grey shades (limited by the square area covered by the model) - La ligne grise désigne l'aire de répartition actuelle de l'espèce. Les polygones blancs représentent des régions élevées : (a) Monts de Cristal, (b) Monts Doudou, (c) Massif du Chaillu et (d) Massif du Mayombe. Ces massifs pourraient correspondre à des zones refuges lors du Dernier Maximum Glaciaire et auraient donné naissance aux quatre unités génétiques distinctes représentées par les différentes nuances de gris (limitées par la surface carrée couverte par le modèle); Source: Born et al., 2011 (modified with permission - modifié avec autorisation).

not regenerate in the forest understory. As the stand increases in age, A. klaineana is gradually replaced by more shade tolerant species, leaving only scattered individuals in mature forests. The abundance of young individuals is therefore inversely proportional to the age of the forest (Doucet et al., 2004).

Fuhr et al. $(1998,2001)$ distinguish three stages of floristic composition following the colonisation of the coastal savannas in Gabon. From settlement to 15-20 years, A. klaineana accounts for $45-70 \%$ stems. From 15-20 years to 30-40 years, it dominates other colonising species reaching $80 \%$ dominance. From the third stage of colonisation ( $>40$ years), most of the other colonising species have disappeared and A. klaineana reaches a peak of between 90 and $95 \%$ of the dominant stratum.

In central Gabon, Marantaceae play a fundamental role in the stand dynamics. Present in the undergrowth of the A. klaineana monodominant forests, they take advantage of the slightest windfall to develop exuberantly. In doing so, they prevent or delay the regeneration of other woody species (White \& Abernethy, 1996; Fuhr et al., 2001).

Monodominant stands of 30 years or more in coastal savanna can have between 300 and 500 stems. $\mathrm{ha}^{-1}$ (dbh, diameter at breast height $\geq 10 \mathrm{~cm}$ ) (Mapaga et al., 2002). In the Lopé Reserve (central Gabon), floristic surveys describe a number of 175 trees $\cdot$ ha $^{-1}$ in monodominant forest, compared to only 8 trees $(\mathrm{dbh} \geq 10 \mathrm{~cm})$ in old growth Marantaceae forests (called mixed Marantaceae forests) (White et al., 2000).

At the country scale, the average density of A. klaineana is 6.90 stems $\cdot \mathrm{ha}^{-1}(\mathrm{dbh} \geq 20 \mathrm{~cm})$ and the distribution of individuals by diameter class is globally balanced with a greater abundance of small diameter trees (Doucet et al., 2021). However, locally in the oldest forests, the distribution follows a Gaussian curve (Figure 4). Biraud (1959) linked it to the regression of human populations who once lived in the forest. Indeed, from the 1930's onwards the Colonial administration forced villages to resettle along roads and major waterways, resulting in a reduction in the spatial influence of slash-and-burn agriculture (Pourtier, 1989; Engone Obiang et al., 2014) and a reduction in sites favourable to the regeneration of A. klaineana and other pioneer longlived light-demanding species (Morin-Rivat et al., 2017).

\subsection{Phenology}

Aucoumea klaineana is not deciduous. However, it renews its leaves simultaneously (Meunier et al., 2015). In some years and across extensive areas leafing occurs following large scale defoliation by a moth (Sylepta balteata Fab.) (Leroy Deval, 1976b; White \& Abernethy, 1996; Mapaga et al., 2002; van Valkenburg, 2008).

In Gabon, A. klaineana flowers at the beginning of the long rainy season, in October (Doucet, 2003). Although it can be fertile from $23 \mathrm{~cm}$ diameter, full flowering is observed from $55 \mathrm{~cm}$ diameter (Doucet, 2003). It is pollinated by social (Apidae: Apinae, Meliponinae) and solitary bees (Xylocopidae) and by flies (Diptera: Calliphoridae, Syrphidae) (Brunck et al., 1990). According to Gautier-Hion (1997), 


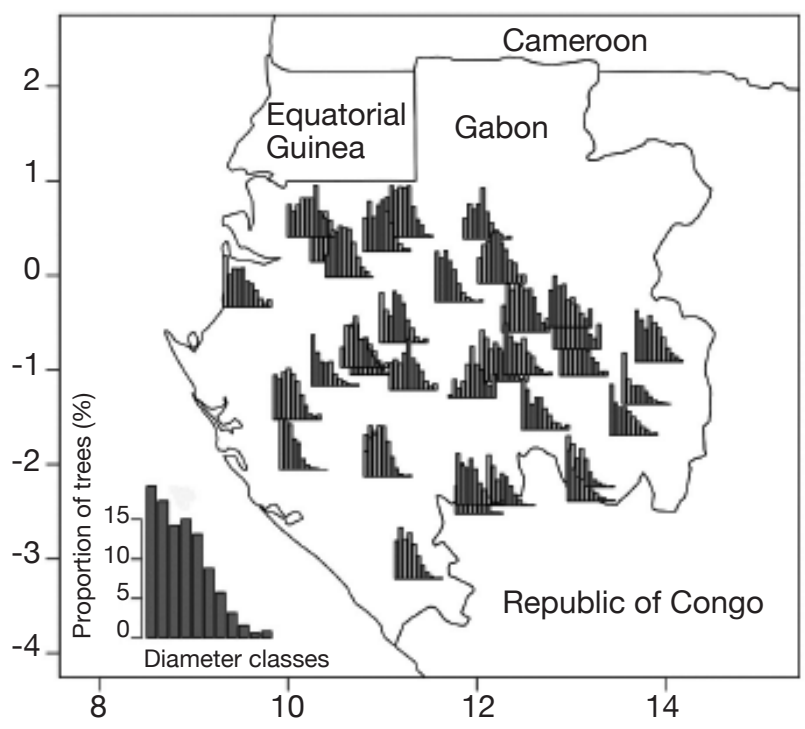

Figure 4. Diametric distribution of Aucoumea klaineana in 35 logging concessions in Gabon, covering 7,3 millions of hectares. The graph on the bottom left shows the average diametric structure at the country scale. Diameter classes start from $20 \mathrm{~cm}$, have a $10 \mathrm{~cm}$ range and are incremented of $10 \mathrm{~cm}$ per class - Distribution diamétrique d'Aucoumea klaineana dans 35 concessions forestières $d u$ Gabon couvrant un total de 7,3 millions d'hectares. Le graphique en bas à gauche montre la structure diamétrique moyenne de l'essence à l'échelle du pays. Les classes de diamètres commencent à partir de $20 \mathrm{~cm}$, ont une amplitude de $10 \mathrm{~cm}$ et sont incrémentées de $10 \mathrm{~cm}$ par classe.

Apis mellifera bees can carry out the pollination of two individuals separated by a maximum of $1.5 \mathrm{~km}$. Fruiting is episodic and supra-annual (Hecketsweiler, 1992). On average, there is only one year of abundant fruiting every three years (Leroy Deval, 1976a).

In Gabon, female trees of A. klaineana start to bear fruit at the end of December, during the short dry season. A "good seed carrier" gives an average of 10 to 30 litres of seeds (there are 800 to 850 seeds per litre). Production depends on the diameter and height of the tree; some dominant trees could produce up to 100 litres (Leroy Deval, 1976a).

Dispersal is by wind. The seeds of a tree of 50 to $60 \mathrm{~cm}$ in diameter, with a well-developed crown can be dispersed up to $100 \mathrm{~m}$ (Doucet, 2003). Dominant winds thus play a decisive role in the spatial distribution of seeds.

\subsection{Natural regeneration}

In contrast to the rest of the life cycle of A. klaineana, germination can take place in the shade and usually 5 to 6 days after sowing. The germination rate drops sharply after 2 to 3 weeks in natural conditions.
Germination depends on temperature (at least $15^{\circ} \mathrm{C}$ ), and soil moisture (at least $2 \%$ ).

A number of factors determine good regeneration (Biraud, 1959):

- a sufficient number of seed trees (4 to 8 per hectare);

- abundant fruiting and sowing;

- a large gap (minimum a quarter hectare);

- perfectly clear soil at the time of sowing.

These conditions can be met in savannas or in cassava and banana field fallows, as harvesting can match the fruiting periods of A. klaineana (Figure 5). Monospecific stands established naturally can have a density ranging from 6,000 (De Kam et al., 1996) to 35,000 seedlings per hectare (Fuhr et al., 1998). At six years, Mapaga et al. (2002) cite a natural stand of 2,650 stems per hectare. By contrast, seedlings and saplings are rare in mature forest stands. They can only be observed in some large openings caused by storms or landslides.

In production forests, logging, which results in an average removal of one to two stems per hectare, does not create sufficient disturbances to allow a significant regeneration of the species. Doucet (2003) surveyed an average of 110 seedlings of A. klaineana per hectare in old-growth secondary forests logged four years earlier. On average, the density of young trees of more than $2 \mathrm{~m}$ in height does not exceed three individuals per hectare of logging gap (Doucet, 2003). Abundant regeneration is only observed along the main roads and in old log yards (Biraud, 1959; Doucet, 2003). This is said to be due to the elimination of competing species from the soil seed bank (Doucet, 2003; Doucet et al., 2004). Doucet (2003) observed average densities of 11 stems $(\mathrm{dbh} \geq 10 \mathrm{~cm})$ of A. klaineana per hectare along 20-year-old logging roads.

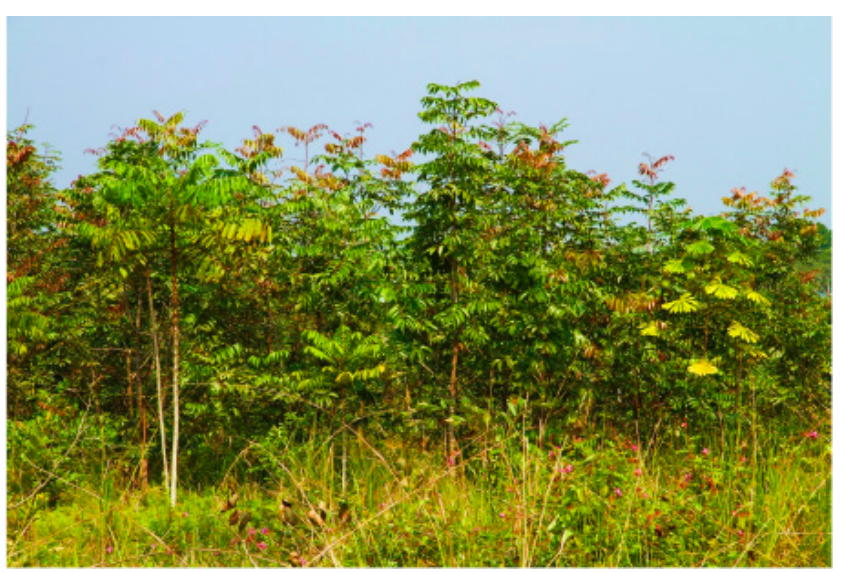

Figure 5. Regeneration of Aucoumea klaineana in a savanna - Régénération d'Aucoumea klaineana dans une savane. 


\subsection{Soil and rhizosphere}

Soil and litter. Aucoumea klaineana grows on all types of soil. From the sandy, poorly drained soils of the estuary of Gabon to the drier, more clay-rich continental soils. Soil type has a minor influence on the establishment of A. klaineana populations compared to climatic and biotic factors (Leroy Deval, 1974).

In the tropics, mineral elements come directly from the litter and not from deep in the soil (Midoko Iponga et al., 2019). Aucoumea klaineana "creates" its own soil, drawing most of its resources from the litter formed by its own fallen fragments (Midoko Iponga et al., 2019), which can be up to $25 \mathrm{~cm}$ thick (Leroy Deval, 1974). Different categories of microorganisms, including mycorrhizal fungi, contribute to rapid nutrient renewal in the litter.

During savanna colonisation, the soil is dry and poor in litter and the roots of A. klaineana go deep into the soil. During the cycle until the formation of an old forest, there is a simultaneous evolution of the plant cover, the moisture content of the soil, the accumulation of litter on the surface, fostered by the presence of other species in the understory, and an upward movement of the rhizosphere of A. klaineana towards the more superficial horizons (Leroy Deval, 1974).

Floristic composition therefore plays an important role in the prosperity of A. klaineana. Commensal species improve litter quality (Leroy Deval, 1974). Reduced leaf turnover in well-formed tree crowns and the removal of secondary species under continuous canopy cover could therefore favor the decline of stands in old-growth forests (Leroy Deval, 1974).

Root anastomoses. Root grafts are common in woody species (Graham \& Bormann, 1966; Mudge et al., 2009). Root anastomoses (or root grafts) refer to as a fusion of root steles allowing an exchange of water, carbon, minerals and/or microorganisms between individuals. However, the physiological mechanisms involved, and their importance are poorly understood (Bader \& Leuzinger, 2019), even though, they are often debated (Graham \& Bormann, 1966; Eis, 1972; LevYadun, 2011).

In A. klaineana, root anastomoses were first described by Catinot (1962) and detailed by Leroy Deval (1973). Stump healing was observed in 5-15\% of cases in natural forests and in $30 \%$ of cases in the plantations studied (Leroy Deval, 1973). The survival of these individuals over a long period after felling (up to 42 years [DIARF et al., 2000]) supposes the transfer of photoassimilates by their neighbours reaching the canopy through root anastomoses or by mycorrhizal associations.

In plantations ( 5 to 15 years), root grafts begin to be observable from $400-500$ trees $\cdot$ ha $^{-1}$ in 0 to $5 \%$ of cases.
When the plantation density reaches 1,500 trees $^{-} \cdot \mathrm{ha}^{-1}$ or more, the rate of stumps kept alive reaches $30 \%$ (Leroy Deval, 1973).

According to Leroy Deval (1973), soil type has no influence on root grafts. However, given that the root system of a tree extends wider in sand compared to clay (Kozlowski \& Pallardy, 1997), soil texture may have an influence on the establishment of fusions between trees at different distances.

The establishment of anastomoses occurs from the age of 4 to 6 years, when there is a differentiation between the dominant and dominated strata and fusions only form between individuals of different social classes. The growth of the dominant stratum is not affected by variations in the density of the dominated stratum (Leroy Deval, 1973).

Mycorrhizal symbioses. Knowledge of the mycorrhizal status of A.klaineana is very limited. Only one paper on the topic was found (Onguene et al., 2002). According to the authors, who observed symbiosis in plantations and in natural regeneration in southern Cameroon (outside the species range), all trees are related to different species of Glomales (arbuscular mycorrhizal fungi) now reclassified in the Glomerales order (Schüßler et al., 2001). Up to the age of 15 years mycorrhizal colonisation rate increases but then decreases in a non-significant manner. However, the quantities of septate hyphae and arbuscles are low. The highest rates of arbuscles are found in young individuals undergoing natural regeneration. In Burseraceae, Bechem et al. (2018) also found AMF on Dacryodes edulis (G.Don) H.J.Lam.

Although the ectomycorrhizal families of tropical Africa do not include the Burseraceae (Bâ et al., 2011), it should be noted that the particular morphology of the fine roots of $A$. klaineana is very similar to pear- or club-shaped structures induced by ectomycorrhizal fungi (Figure 6).

\section{GROWTH DYNAMICS AND DETERMINISM}

\subsection{Measuring techniques and average growth rates in diameter}

Thousands of increment measurements have been carried out on A. klaineana since the 1950s (FAO, 1981; Rocek, 1981; Brunck et al., 1990; Fuhr, 1999; DIARF et al., 2000). Mean values are generally reported in the literature, but measurement techniques (permanent plot and ring analysis) may give different results (Détienne et al., 1998).

Engone Obiang et al. (2013) compiled the average growth rate for A. klaineana since 1961 in permanent plots established in natural stands. Average annual 
increases in diameter and per individual ranged from 0.1 to $2.33 \mathrm{~cm} \cdot \mathrm{yr}^{-1}$. This compilation shows that the information is not always comparable between sites, because the diameter classes considered are different (from 0 to $>100 \mathrm{~cm}$ ) and the numbers of observations are sometimes insufficient. This results in very high standard errors.

Ring counts were tested on A. klaineana in the early 1960s by Mariaux and Catinot (Mariaux, 1967). Gabonese (and Congolese) climate generally has four seasons: a long and a short rainy season and a long and short dry season. This alternation makes it possible to observe biennial rings in A. klaineana under optimal conditions and thus to trace its growth dynamics (Détienne et al., 1998). However, measurements are reported to be easy to difficult depending on the growth rate of the tree (Rivière, 1992; Détienne et al., 1998). Ring analyses gave the following average annual diameter increments: 9,4 $\mathrm{mm}$ (Sindara, Gabon), 7 to $15 \mathrm{~mm}$ (Oyane, Gabon) and 5 to $6 \mathrm{~mm}$ (interior Gabon).

By synthesizing all available data (plots and ring analysis) on A. klaineana growth, Picard \& GourletFleury (2011) obtain an average annual increase of $8 \mathrm{~mm}$ in unlogged forests. However, according to some authors, A. klaineana grows faster in coastal areas than in the interior of Gabon (Brunck et al., 1990; Durrieu de Madron et al., 2000). According to Mapaga et al. (2002), the dominant and codominant individuals in the coastal zone grow an average of $10 \mathrm{~mm} \cdot \mathrm{yr}^{-1}$ in diameter compared to $6 \mathrm{~mm} \cdot \mathrm{yr}^{-1}$ in the continental zone. Growth rate is said to be a maximum at 10 years. According to other authors, there are no differences between coastal and continental areas (Croisé \& Fabbri, 1991).

Local factors such as stand structure (density, age, mix, etc.) and disturbances (logging, fire, competition, etc.) are sources of significant variations in the growth of A. klaineana (Engone Obiang et al., 2013). Durrieu de Madron et al. (2000) report that A. klaineana in mixed stands grows more rapidly below $30 \mathrm{~cm}$ (dbh) and that this speed decreases from $40 \mathrm{~cm}$ (dbh) onwards. But, according to Nasi (1997), the rate of growth increases constantly for even-aged stands.

\subsection{Growth models for Aucoumea klaineana}

The first model for A. klaineana was constructed from data from Oyan (Gabonese coastal zone) (Louppe et al., 2000; Mapaga et al., 2002).

Engone Obiang et al. (2013) developed a lognormal rate formula for stands from six sites. The model estimates the growth rate $\left(\mathrm{A}\right.$, in $\left.\mathrm{cm} \cdot \mathrm{yr}^{-1}\right)$ including the diameter of the studied tree $(\mathrm{D}$, in $\mathrm{cm})$, the stand density ( $\mathrm{N}$, per hectare) and the basal area of the stand $\left(\mathrm{B}\right.$, in $\left.\mathrm{m}^{2} \cdot \mathrm{ha}^{-1}\right)$. The last two parameters concern all species in the vicinity of the tree studied, which gives information on its biotic environment:

$$
A=2.26 \exp \left\{-\left[\frac{1}{1.26} * \ln \left(\frac{21.0}{D}\right)\right]^{2}-\left(0.121 * B-6.038 * 10^{-4} * N\right) * \exp \left(-3.350 * 10^{-2} * D\right)\right\}
$$

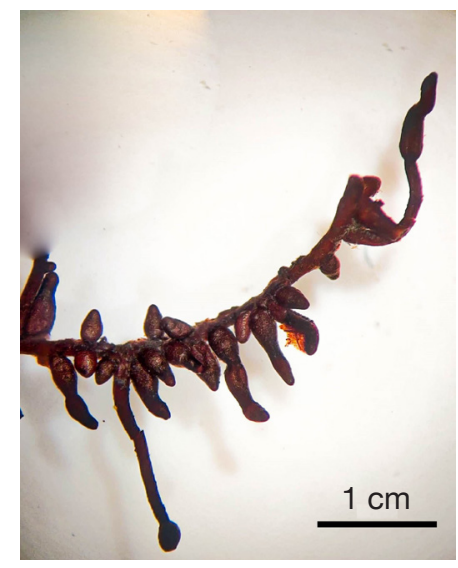

Figure 6. Typical fine root of Aucoumea klaineana. The thinnest elements are pear- or club-shaped, suggesting ectomycorrhizal structures - Racine fine typique d'Aucoumea klaineana. Les éléments les plus fins, en forme de poire ou de massue, font penser à des structures ectomycorhiziennes.
By using the average values of basal area and density calculated from the Gabonese national inventory data $\left(25 \mathrm{~m}^{2} \cdot \mathrm{ha}^{-1}\right.$ and 410 stems $\cdot \mathrm{ha}^{-1}$; Poulsen et al., 2020), the diameter growth of $A$. klaineana peaks between 40 and $70 \mathrm{~cm}$ and then decreases (Figure 7).

\section{SILVICULTURE}

\subsection{Artificial regeneration}

The history of A. klaineana silviculture in Gabon is detailed by Brunck et al. (1990). The main results are summarized hereafter.

\section{Monospecific plantations}

Density. A density of between 625 and 950 stems $\cdot$ ha $^{-1}$ seems optimal until a first thinning at 4 years, which reduces the density of the plantation to $350 \mathrm{stems} \cdot \mathrm{ha}^{-1}$. 


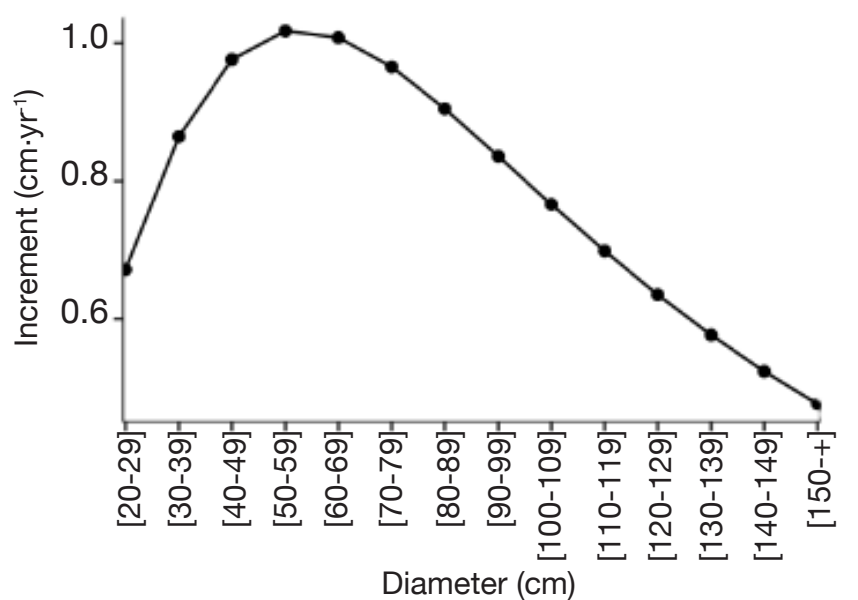

Figure 7. Illustration of the growth model used - Illustration du modèle de croissance utilisé.

This is the model proposed by Engone Obiang et al. (2013) with a basal area of $25 \mathrm{~m}^{2} \cdot \mathrm{ha}^{-1}$ and a density of 410 stems $\cdot \mathrm{ha}^{-1}-$ Il s'agit du modèle proposé par Engone Obiang et al. (2013) en fixant la surface terrière à $25 \mathrm{~m}^{2} \cdot \mathrm{ha}^{-1}$ et la densité à 410 tiges $^{\prime} \cdot \mathrm{ha}^{-1}$.

This range makes it easy to find a good compromise between bole quality and plantation cost price (Leroy Deval, 1976a). A lower density can lead to higher mortality related to the lack of root anastomoses in the stand because of the distance between roots and to a greater competition with various species depending on the region of the plantation (Louppe et al., 2000).

Considering the biology of the species, Louppe et al. (2000) propose to plant the species in plots with a density of 9 to 16 plants disposed at $1 \mathrm{~m}$ apart to promote the formation of root anastomoses. Spacing these plots $12 \times 12 \mathrm{~m}$ or $10 \times 15 \mathrm{~m}$ apart should yield 70 stems $\cdot h^{-1}$.

Thinning. Fuhr et al. (2001) assume that thinning should not take place too late because, after 10 years, the growth gain does not compensate for the loss in basal area. Other authors also advocate thinning out at around 10 years (Leroy Deval, 1974; Bibani, 1987, cited by Onguene et al., 2002). However, Onguene et al. (2002) suggest undertaking only a single thinning around 15 years. Thinning before this age would damage a possible mycorrhizal network and thus the carbon capture.

Leroy Deval (1973) recommends two thinnings, between 8 and 15 years of age, in order to promote the good health of the plantation while maintaining good bole conformation.

Costs. Louppe et al. (2000) compare clear-cutting and monospecific natural or artificial regeneration to selective harvesting every 30 years above 60 or $70 \mathrm{~cm}$ in diameter. Not conclusive for either method, they state that in the case of clearcutting, harvesting allows natural or artificial regeneration of A. klaineana immediately afterwards. However, the operation releases a large amount of carbon and the market for A. klaineana wood is not suitable for small-diameter stems. In the case of selective logging, they specify that after the $3^{\text {rd }}$ cutting cycle, an enrichment or a new plantation is essential because the trees exploited will not have formed openings large enough for the species to regenerate by itself. Exploitation by clear-cutting would cost 1,641,200 FCFA.ha ${ }^{-1}\left(2,502 € \cdot\right.$ ha $\left.^{-1}\right)$ against 295,500 FCFA $\cdot \mathrm{ha}^{-1}\left(450 € \cdot \mathrm{ha}^{-1}\right)$ for enrichment after selective cutting (conversions from FCFA to euro are in relation to 2020).

\section{Multi-species plantations}

Multi-species plantation tests on thirteen species were carried out at the Ekouk experimental site between 1988 and 1994 (Koumba Zaou et al., 1998). Planting was carried out either after clearcutting and clearing of the soil, or using the undergrowth method, by clearing the shrub and herbaceous layers and ringing trees of little interest.

The study showed that A. klaineana grows faster in diameter in clearcutting (about $2.3 \mathrm{~cm} \cdot \mathrm{yr}^{-1}$ compared to $2 \mathrm{~cm} \cdot \mathrm{yr}^{-1}$ in undergrowth), while the undergrowth method favours better tree form and at a lower cost (about half that of clearcutting). In both cases, it grows in height by about $2.4 \mathrm{~m} \cdot \mathrm{yr}^{-1}$. Basal area, reached $9.2 \mathrm{~m}^{2} \cdot \mathrm{ha}^{-1}$ in clearcutting after six years, compared to $6.9 \mathrm{~m}^{2} \cdot \mathrm{ha}^{-1}$ in undergrowth. Koumba Zaou et al. (1998) cite costs of about 800,000 FCFA.ha- ${ }^{-1}(1,219 €)$ for clearcutting and 316,000 FCFA $^{-1} \mathrm{ha}^{-1}(481 €)$ for the undergrowth method.

\subsection{Assisted natural regeneration}

Doucet et al. (2004) tested an assisted natural regeneration technique in 10 plots ranging from 0.3 to $1.6 \mathrm{ha}$. These plots were centred on well-formed, A. klaineana stems with healthy fruit crops just before the seeds were released. The undergrowth was removed with a machete. Then, trees and shrubs of noncommercial species were felled.

The results obtained were very cheering. After six months, the density of A.klaineana seedlings was $0.38 \mathrm{~m}^{-2}$. The average annual growth in height of the seedlings was $86 \mathrm{~cm}$, reaching $196 \mathrm{~cm}$ for the dominant ones. In 2003, the costs were estimated at 233,000 FCFA. ha $^{-1}$ (356€) (without depressing or clearing).

\section{FOREST MANAGEMENT}

In Central Africa, logging is subject to legislation aimed at ensuring the sustainable management of forest resources. Trees must reach a minimum cutting 
diameter (MCD) before they can be exploited. In Gabon and Congo, the MCD of A. klaineana is set at $70 \mathrm{~cm}$ (Decree No. 1993-11285, Law 1-82 [Gabon]; Decree $\mathrm{n}^{\circ} 2002-437$ [Congo]), while it is $80 \mathrm{~cm}$ in Cameroon (ONADEF, 1992).

This MCD may need to be revised upwards in order to meet national standards in terms of recovery rates. For A. klaineana, this rate must be at least $75 \%$ in Gabon and 50\% in Cameroon. In Congo, the rates are calculated by species group and not individually. These rates are calculated for a cutting cycle. This time is a minimum of 20 years in Gabon (Law n ${ }^{\circ} 016 / 01$ ), 25 to 30 years in Congo (Karsenty et al., 2016) and 30 years in Cameroon (ONADEF, 1992).

\section{WOOD MARKET}

\subsection{Use}

The characteristics of A. klaineana wood are described in Gérard et al. (2016). It is one of the best timbers for veneer and plywood production. The exploitation of $A$. klaineana was once very selective. It was limited to the best shaped trees for the wood peeling industry. With the new market demands to process lower-quality logs by sawing, the proportion of A. klaineana actually exploited sharply increased in some concessions in Gabon, from 30-40\% during the 1990 s to $65-75 \%$ today (FRMi, 2018). The physicomechanical characteristics of plantation woods are very close to those of natural forests (Ngavoura, 1998; Medzegue et al., 2007).

\subsection{Market}

In Gabon, in 2007, A. klaineana accounted for $930,000 \mathrm{~m}^{3}$ of wood entering factories, $82 \%$ of Gabon's total production (de Wasseige et al., 2009). In 2010, the Gabonese government banned the export of logs. This strongly encouraged local wood processing (Yoan et al., 2018) and the export of veneers to the European market which reached $142,000 \mathrm{~m}^{3}$ in 2017 (ITTO, 2019). On the other hand, other producing countries (Congo and Equatorial Guinea) have taken advantage of this ban to export more logs to China. For example, Congo increased its exports of A. klaineana logs by $20 \%$ between 2016 and 2017 to reach $940,000 \mathrm{~m}^{3}$ (ITTO, 2019). Since July 2020, Congo has also banned the export of logs except "logs of heavy and hardwood species whose processing requires specific technology" (art.97, Law No.33-2020). In 2018, sawn timber was mainly directed to China $(61 \%)$, Vietnam (15\%) and Belgium (6\%) (ITTO, 2019).

According to recent modelling (FRMi, 2018), the net volume that could be mobilised would be between
1.88 and 2.71 million $\mathrm{m}^{3} \cdot \mathrm{yr}^{-1}$, whereas the volumes harvested reach 1.70 million $\mathrm{m}^{3} \cdot \mathrm{yr}^{-1}$.

As approximations given only for information purposes, A. klaineana logs sold between 2015 and 2020 to China ranged $160-250 € \cdot \mathrm{m}^{-3}$. For sawn timber, $270-460 € \cdot \mathrm{m}^{-3}$ (pers. com. in line with the latest ITTO tropical timber market report, https://www.itto.int/ market_information_service/). Veneer sheets for the European FSC market can be sold for around 800$860 € \cdot \mathrm{m}^{-3}$ for face and back and $450 € \cdot \mathrm{m}^{-3}$ for cores (pers. com.). According to FRMi (2016), Asian buyers were spending $280-380 € \cdot \mathrm{m}^{-3}$ for Gabonese plywood compared to $660-850 € \cdot \mathrm{m}^{-3}$ towards the European FSC market. It should also be noted that current prices are high due to the SARS-COV2 pandemic.

\section{CONCLUSIONS AND STUDY PERSPECTIVES}

Aucoumea klaineana is classified by the IUCN as "Vulnerable" under criterion A1. This criterion considers the past reduction of the species' population over a period of three generations. Given their long lifespan, this criterion is difficult to objectivise for tree species. Like populations of other light-demanding colonising taxa, it is even likely that A. klaineana populations have increased over the past few centuries as explained in this review. Furthermore, with an average of 6,9 trees $(\mathrm{dbh} \geq 20 \mathrm{~cm})$ per hectare, the species is not rare and its regeneration is not problematic at the level of its distribution range. Finally, in logging concession, the exploitation leaves enough seed trees because the legal cutting diameter is well above the fruiting diameter. Therefore, we do not believe that $A$. klaineana is vulnerable under criterion A1.

While logging is not a concern for the survival of the species, the reduction in the quality of the logs due to decades of exploitation focused on the best shaped trees, could have unfortunate consequences on the quality of the production.

Optimising A.klaineana silviculture and thus maintaining its trade is essential for the economic future of Gabon and bordering regions. This species remains the leader in a niche market which is the production of veneer sheets by peeling.

It has been shown that the wood quality of A. klaineana in plantations is comparable to that of natural forest wood (Medzegue et al., 2007). The success of plantations should make it possible to keep a low pressure on the natural resource by concentrating production on small areas. Furthermore, the lightdemanding temperament as well as the rapid growth of the species should ensure that A. klaineana is a prime choice for regenerating degraded forests and recreating a habitat suitable for restarting the forest dynamics. 
To improve stand management and ensure sufficient regeneration of the species, it is important to understand the determinants of its growth. This synthesis has revealed a high variability in the growth and productivity of natural and artificial stands of A. klaineana. It also highlighted the lack of knowledge about the role of the rhizosphere in the dynamics of the species populations. To be effective, silviculture of A. klaineana should take these aspects into account to a greater extent (Leroy Deval, 1976a).

Mycorrhizal symbiosis in A. klaineana roots has never been observed in its area of origin. However, it could explain the mixed productivity of the species, in comparison with other light-demanding species in plantations.

The phenomenon of root anastomoses could also be a determining factor in the dynamics of A. klaineana populations by promoting strata differentiation in stands and extending the rhizosphere of dominant trees while providing photoassimilates to the dominated. This phenomenon could be complementary with mycorrhizae. It is therefore necessary to improve our knowledge of the rhizosphere of populations of the most exploited woody species in Central Africa.

\section{Acknowledgements}

The authors would like to thank the "Projet d'Appui à la Filière Forêt Bois", Nathalie Nyare Essima, David Ingueza, Eric Haudiquet and Abrahm Ndogou. Many thanks as well to Félicien Tosso $($ Nature +) and Gauthier Ligot (Gembloux Agro-Bio Tech) for the help on figures conception, Dominique Louppe (CIRAD) and Jean-Yves De Vleeschouwer for digging out archives needed to write this review.

\section{Bibliography}

Aboughe Angone S., Aworet Samseny R.R.R. \& Eyele Mve Mba C., 2015. Quelques propriétés des huiles essentielles des plantes médicinales du Gabon. Phytothérapie, 13(5), 283-287, doi.org/10.1007/s10298-014-0905-z

Anthony N.M. et al., 2007. The role of Pleistocene refugia and rivers in shaping gorilla genetic diversity in central Africa. PNAS, 104(51), 20432-20436, doi.org/10.1073/ pnas.0704816105

ATIBT (Association Technique Internationale des Bois Tropicaux), 2016. Nomenclature générale des bois tropicaux. Paris : ATIBT.

Aubréville A., 1948. Étude sur les forêts de l'Afrique équatoriale française et du Cameroun. Nogent-surMarne, France : CIRAD-IRAT, 131.

Aubréville A., 1962. Burséracées. Flore du Gabon. Vol. 3. Paris : Museum National d'Histoire Naturelle, 53-95.

Bâ A., Duponnois R., Diabaté M. \& Dreyfus B., 2011. Les champignons ectomycorhiziens des arbres forestiers en Afrique de l'Ouest: méthodes d'étude, diversité, écologie, utilisation en foresterie et comestibilité. Marseille, France : IRD Éditions, 269.

Bader M.K.-F. \& Leuzinger S., 2019. Hydraulic coupling of a leafless kauri tree remnant to conspecific hosts. iSciences, 19, 1238-1243, doi.org/10.1016/j. isci.2019.05.009

Bechem E., Njoh N. \& Egbe A., 2018. Mycorrhizal status of some indigenous tree species in the Takamanda rainforest, South West Region, Cameroon. J. Ecol. Nat. Environ., 10(3), 41-52, doi.org/10.5897/JENE2018.0684

Biraud J., 1959. Reconstitution naturelle et amélioration des peuplements d'okoumé du Gabon. Bois For. Trop., 66 , 3-28.

Born C. et al., 2011. Insights into the biogeographical history of the lower Guinea forest domain: evidence for the role of refugia in the intraspecific differentiation of Aucoumea klaineana. Mol. Ecol., 20, 131-142, doi. org/10.1111/j.1365-294X.2010.04919.x

Brunck F., Grison F. \& Maître H.-F., 1990. L'okoumé. Nogent-sur-Marne, France : CIRAD-CTFT, 102.

Catinot R., 1962. Note sur les croissances de l'okoumé en plantations artificielles serrées: ses possibilités en plantation à courte révolution. Bois For. Trop., 85, 13-23.

Croisé L. \& Fabbri B., 1991. Les tâches naturelles d'okoumé au Congo (massif du Chaillu), dispositif d'étude et évolution selon des interventions sylvicoles simples, résultats préliminaires. Nogent-sur-Marne, France : CIRAD-CTFT.

Dauby G. et al., 2016. RAINBIO: a mega-database of tropical African vascular plants distributions. Phytokeys, 74, 1-18.

De Kam M. et al., 1996. Biologie de l'okoumé. Rapport final de l'appui technique (No. IBN Research Report 96/8). Wageningen, Pays-Bas : Fondation Tropenbos.

de Wasseige C. et al., 2009. Les forêts $d u$ bassin $d u$ Congo : état des forêts 2008. Luxembourg: Office des Publications de l'Union européenne.

DeCarlo A. et al., 2019. The essential oils of the Burseraceae. In: Malik S., ed. Essential oil research: trends in biosynthesis, analytics, industrial applications and biotechnological production. Cham, Switzerland: Springer Nature Switzerland, 72-145, doi. org/10.1007/978-3-030-16546-8

Delègue M.-A. et al., 2001. Recent origin of a large part of the forest cover in the Gabon coastal area based on stable carbon isotope data. Oecologia, 129(1), 106-113, doi.org/10.1007/s004420100696

Détienne P., Oyono F., Durrieu de Madron B. \& Nasi R., 1998. L'analyse de cernes: applications aux études de croissance de quelques essences en peuplements naturels de forêt dense africaine. No. 15. Série Forafri. Montpellier, France : CIRAD-Forêt.

DIARF, CIRAD \& IRAF, 2000. Projet No. OIBT PD 10/95 REV.2 (F). Évaluation des essences indigènes de bois d'ceuvre en vue du développement des plantations 
forestières au Gabon. Rapport final. Assistance technique du CIRAD-Forêt, Libreville-Montpellier.

Doucet J.-L., 2003. L'alliance délicate de la gestion forestière et de la biodiversité dans les forêts du centre $d u$ Gabon. Thèse de doctorat : Faculté universitaire des Sciences agronomiques de Gembloux (Belgique).

Doucet J.-L., Nchandi Otimbo P.-A. \& Boubady A.-G., 2004. Comment assister la régénération naturelle de l'okoumé dans les concessions forestières ? Bois For. Trop., 279, 59-72.

Doucet J.-L., Ligot G., Guidosse Q. \& Tosso F., 2021. Évaluation du statut de vulnérabilité de l'okoumé au Gabon (No. Contrat de service $n^{\circ} 010$ PAFFB). Gembloux, Belgique : Nature+ asbl \& Gembloux AgroBio Tech.

Durrieu de Madron L., Nasi R. \& Détienne P., 2000. Accroissements diamétriques de quelques essences en forêt dense africaine. Bois For. Trop., 263(1), 63-74.

Eis S., 1972. Root grafts and their silvicultural implications. Can. J. For. Res., 2(111), 111-119.

Engone Obiang N.L. et al., 2013. Disentangling the effect of size and competition: a growth model for Aucoumea klaineana. Ann. For. Sci., 70(3), 241-249, doi. org/10.1007/s 13595-012-0255-7

Engone Obiang N.L. et al., 2014. Diagnosing the demographic balance of two light-demanding tree species populations in central Africa from their diameter distribution. For. Ecol. Manage., 313, 55-62, doi. org/10.1016/j.foreco.2013.10.045

FAO, 1981. Tropical forest resources assessment project (in the framework of the global environment monitoring system-GEMS). Forest resources of tropical Africa. Part II: country briefs (Tech Rep No. 2). Roma: FAO \& UNEP.

Favier C., De Namur C. \& Dubois M.-A., 2004. Forest progression modes in littoral Congo, central atlantic Africa: forest progression modes in Congo. J. Biogeogr., 31(9), 1445-1461, doi.org/10.1111/j.13652699.2004.01094.x

FRMi (FRM Ingénierie), 2018. Rapport stratégique régional. Développement intégré et durable de la filière bois dans le Bassin du Congo : opportunités, défis et recommandations opérationnelles. Montpellier, France : FRMi.

Fuhr M., 1999. Effet de l'éclaircie sur la dynamique et la production des peuplements purs d'okoumé en zone côtière du Gabon. In : Actes du séminaire Forafri sur la gestion des forêts denses africaines aujourd'hui , 12-16 octobre 1998, Libreville, Gabon. Montpellier, France : CIRAD-Forêt, CIFOR, FORAFRI.

Fuhr M., Delegue M.-A., Nasi R. \& Minkoué J.-M., 1998. Dynamique et croissance de l'okoumé en zone côtière du Gabon (No. 16). Montpellier, France : Forafri, CIRADForêt.

Fuhr M., Nasi R. \& Delegue M.-A., 2001. Vegetation structure, floristic composition and growth characteristics of Aucoumea klaineana Pierre stands as influenced by stand age and thinning. For. Ecol. Manage., 140(2-3), 117-132, doi.org/10.1016/S0378-1127(00)00320-0

Gautier-Hion A., 1997. Les forêts d'Afrique centrale : essai comparé sur la biodiversité et les relations sol-fauneflore (rapport final No. UMR 373). Paimpont, France : CNRS-Université de Rennes 1.

GBIF (The Global Biodiversity Information Facility), 2020. GBIF, http://www.gbif.org/what-is-gbif, (01/11/2020).

Gérard J., Guibal D., Paradis S. \& Cerre J.C., 2016. Atlas des bois tropicaux. Versailles, France : Éditions Quæ.

Graham B.F. \& Bormann F.H., 1966. Natural root grafts. Bot. Rev., 32(3), 255-292, doi.org/10.1007/BF02858662

Grison F., 1978. Note sur les fleurs de l'okoumé (Aucoumea klaineana Pierre, Burseraceae). Andansonia, séries 2, 17(3), 335-342.

Hecketsweiler P., 1992. Phénologie et saisonnalité en forêt gabonaise, l'exemple de quelques espèces ligneuses. Thèse de doctorat : Université de Montpellier II (France).

Hymas O., 2015. L'okoumé, fils du manioc: Post-logging in remote rural forest areas of Gabon and its long-term impacts on development and the environment. $\mathrm{PhD}$ thesis: University College London (UK).

ITTO, 2019. Revue biennale et évaluation de la situation mondiale des bois 2017-2018. Yokohama, Japon : Organisation Internationale des Bois Tropicaux.

Karsenty A. et al., 2016. L'aménagement forestier au Congo engendre-t-il plus de déforestation? CIRAD.

Koumba Zaou P., Nze Nguema S., Mapaga D. \& Deleporte P., 1998. Croissance de 13 essences de bois d'œuvre plantées en forêt gabonaise. Bois For. Trop., 256, 21-33.

Kozlowski T.T. \& Pallardy S.G., 1997. Physiology of woody plants. San Diego, Ca, USA: Academic Press.

Leroy Deval J., 1973. Les liaisons et anastomoses racinaires. Bois For. Trop., 152, 37-49.

Leroy Deval J., 1974. Structure dynamique de la rhizosphère de l'okoumé dans ses rapports avec la sylviculture. Nogent-sur-Marne, France : CIRAD-CTFT, 121.

Leroy Deval J., 1976a. Biologie et sylviculture de l'okoumé (Aucoumea klaineana Pierre). Tome 1 : La sylviculture de l'okoumé. Nogent-sur-Marne, France: CIRADCTFT, 355.

Leroy Deval J., 1976b. Biologie et sylviculture de l'okoumé (Aucoumea klaineana Pierre). Tome 2: Maladies et défauts de l'okoumé. Nogent-sur-Marne, France: CIRAD-CTFT, 75.

Lev-Yadun S., 2011. Why should trees have natural root grafts? Tree Physiol., 31(6), 575-578, doi.org/10.1093/ treephys/tpr061

Louppe D., Hamel O., Jaffre R. \& Roda J.M., 2000. Étude coûts et bénéfices des plantations d'okoumé au Gabon. Rapport final. Projet forêts et environnement. Libreville : Ministère des eaux et forêts, de la pêche, du reboisement, chargé de l'environnement et de la protection de la nature du Gabon, 202. 
Mapaga D., Ingueza D., Louppe D. \& Koumba-Zaou P., 2002. Okoumé (No. 27). Montpellier, France : Forafri, CIRAD-Forêt.

Mariaux A., 1967. Les cernes dans les bois tropicaux africains, nature et périodicité. Bois For. Trop., 113, 3-14.

Medzegue M.J. et al., 2007. Radial growth and characterization of juvenile and adult wood in plantation grown okoumé (Aucoumea klaineana Pierre) from Gabon. Ann. For. Sci., 64(8), 815-824, doi.org/10.1051/ forest:2007065

Meunier Q., Moumbogou C. \& Doucet J.-L., 2015. Les arbres utiles $d u$ Gabon. Gembloux, Belgique: Les Presses agronomiques de Gembloux, 340.

Midoko Iponga D.M., Mpikou R.G.J., Loumeto J. \& Picard N., 2019. The effect of different anthropogenic disturbances on litterfall of a dominant pioneer rain forest tree in Gabon. Afr. J. Ecol., 58(2), 281-290, doi. org/10.1111/aje.12696

Morin-Rivat J. et al., 2017. Present-day central African forest is a legacy of the $19^{\text {th }}$ century human history. eLife, 6(e20343), 1-18, doi.org/10.7554/eLife.20343

Mudge K., Janick J., Scofield S. \& Goldschmidt E.E., 2009. A history of grafting. In: Janick J., ed. Horticultural reviews. Hoboken, NJ, USA: John Wiley \& Sons, Inc., 437-493.

Muloko-Ntoutoume N.etal., 1999. Utilisation des marqueurs moléculaires dans la reconstitution de l'histoire de la forêt tropicale humide gabonaise : le modèle Aucoumea klaineana. In: Nasi R., Amsallem I. \& Drouineau S., éds. Actes du séminaire Forafri de Libreville, session 2 : connaissance de l'écosystème. Montpellier, France : CIRAD-Forêt.

Nasi R., 1997. Les peuplements d'okoumé au Gabon. Leur dynamique et croissance en zone côtière. Bois For. Trop., 251, 5-27.

Ngavoura P., 1998. Variation inter et intra-arbre des propriétés du bois d'okoumé (Aucoumea klaineana P.). Thèse de master : Université de Nancy - DEA Science du bois (France).

Obame L.-C.E. et al., 2014. Antifungal and antibacterial activities of Aucoumea klaineana Pierre essential oil from Gabon. VRI Phytomed., 2(1), 17, doi.org/10.14259/ pm.v2i1.87

ONADEF, 1992. Normes d'études d'arbres. Yaoundé : Ministère de l'Environnement et des Forêts.

Onguene N.A., Tsimi J.P.M. \& Balla M.J.E., 2002. Statut mycorhizien de l'okoumé (Aucoumea klaineana Pierre) en régénération artificielle au sud Cameroun. Tropicultura, 20(3), 104-108.

Peguy E.A.S. et al., 2019. Extraction and characterization of Aucoumea klaineana Pierre (okoume) extractives. J. Renewable Mater., 7(6), 517-522, doi.org/10.32604/ jrm.2019.04051

Peguy E.A.S. et al., 2020. The condensed tannins of okoume (Aucoumea klaineana Pierre): a molecular structure and thermal stability study. Sci. Rep., 10, n¹773, doi. org/10.1038/s41598-020-58431-7

Philippon N. et al., 2018. Cycles diurnes de rayonnement solaire et forêts en Afrique centrale. In : Martin N., éd. $X X X I^{e}$ colloque annuel de l'Association Internationale de Climatologie sur les échelles spatiales et temporelles fines, 4-7 juillet 2018, Nice, France, 38-42.

Picard N. \& Gourlet-Fleury S., 2011. Projet d'aménagement des petits permis forestiers gabonais. Optimisation des hypothèses et paramètres d'aménagement (No. RT 1106 $N P \& S G F)$. Libreville : Groupement Forest Ressources Management/CIRAD/TEREA.

Poulsen J.R. et al., 2020. Old growth Afrotropical forests critical for maintaining forest carbon. Global Ecol. Biogeogr., 29(10), 1785-1798, doi.org/10.1111/ geb. 13150

Pourtier R., 1989. Le Gabon : état et développement. Paris : L'Harmattan.

Rivière L., 1992. Étude de l'évolution des peuplements naturels d'okoumé (Aucoumea klaineana Pierre) dans le sud-estuaire du Gabon. Construction de tables de croissance provisoires. Thèse de doctorat: Université Pierre et Marie Curie (Paris VI, France).

Rocek L., 1981. Accroissement en diamètre de l'okoumé (Aucoumea klaineana Pierre). Silvaecult. Trop. Subtrop., $\mathbf{8}, 41-50$.

Schüßler A., Schwarzott D. \& Walker C., 2001. A new fungal phylum, the Glomeromycota: phylogeny and evolution. Mycol. Res., 105(12), 1413-1421, doi.org/10.1017/ S0953756201005196.

Telfer P.T. et al., 2003. Molecular evidence for deep phylogenetic divergence in Mandrillus sphinx. Mol. Ecol., 12(7), 2019-2024, doi.org/10.1046/j.1365294X.2003.01877.x

van Valkenburg J.L.C.H., 2008. Aucoumea klaineana Pierre. In : Louppe D., Oteng-Amoako A.A. \& Brink M., eds. PROTA (Plant Resources of Tropical Africa), 7. Wageningen, The Netherlands: PROTA Foundation, 8286.

White L. \& Abernethy K., 1996. Guide de la végétation de la Réserve de la Lopé, Gabon. Libreville : Ecofac, 229.

White L., Oslisly R., Abernethy K. \& Maley J., 2000. L'okoumé (Aucoumea klaineana) : expansion et déclin d'un arbre pionnier en Afrique centrale atlantique au cours de l'Holocène. In : Servant M. \& ServantVildary S.,éds. Dynamique à long terme des écosystèmes forestiers intertropicaux. Paris : UNSECO, 399-411.

Yoan A.O., Xue Y. \& Kiki M.J.M., 2018. Gabon wood industry and Chinese companies activities. Open Access Lib. J., 5(5), 1-15, doi.org/10.4236/oalib.1104553 